\title{
PENINGKATKAN KETERAMPILAN GURU BIMBINGAN KONSELING DALAM PEMEROLEHAN KESIAPAN PSIKOLOGIS SISWA MENGHADAPI BENCANA ALAM
}

\author{
Yulia Ayriza \\ FIP Universitas Negeri Yogyakarta (ayriza_03@yahoo.co.id; HP: 08121576867)
}

\begin{abstract}
Improving Guidance and Counseling Teachers' Skills in the Acquisition of Students' Psychological Preparedness for Natural Disasters. This study aims to investigate whether there is an improvement of school councelors' skills in carrying out personal-social guidance and counseling after joining a module implementation training on the improvement of students' psychological preparedness for natural disasters. This was a quasi-experimental study involving 29 high school counselors in the Province of Yogyakarta Special Territory. The sample was selected using the area quota random sampling technique. The data collecting instruments consisted of a test, scale, and observation. The data were analyzed using the t-test with the SPSS program. The result showed that there was a significant increase in school counselors' skills, before and after the module implementation training, in carrying out personal-social counseling services with the aim of improving students' psychological preparedness for natural disasters.
\end{abstract}

Keywords: school counselors' skills, psychological preparedness for natural disasters

\section{PENDAHULUAN}

Bimbingan dan konseling sebagai salah satu komponen yang integral dari pendidikan mempunyai peranan penting dalam mencapai tujuan pendidikan nasional sebagaimana tercantum dalam UUSPN No. 20 Tahun 2003, yaitu mengembangkan manusia Indonesia seutuhnya yang beriman dan bertaqwa, berbudi pekerti luhur, cerdas dan terampil, sehat jasmani dan rohani, kepribadian yang mantap dan mandiri serta rasa tanggung jawab kemasyarakatan dan kebangsaan. Di sekolah, layanan bimbingan dan konseling bertujuan untuk membantu siswa agar dapat mencapai tujuan-tujuan perkembangan yang meliputi aspek pribadi, sosial, belajar, dan karier (Sugihartono, 1989).

Terkait dengan semakin seringnya terjadi bencana di berbagai daerah dalam dua dekade terakhir ini (UNDP, 2006), ekolah perlu mensikapi dengan membangun ketahan sekolah terhadap bencana. Upaya pembekalan pada siswa sehingga mampu menyiapkan diri menghadapi bencana secara optimal dan efektif, dapat dilakukan melalui bimbingan pada aspek pribadi-sosial (Fathiyah, 2007). Oleh karena itu, layanan yang diberikan sering diistilahkan sebagai layanan pribadi-sosial. Di sekolah, layanan bimbingan pribadi sosial merupakan salah satu bagian layanan dari guru BK kepada siswa se- 
hingga siswa dapat menemukan pribadi, mengenal lingkungan dan merencanakan masa depan. Menemukan pribadi, yaitu mengenal kekuatan dan kelemahan dirinya. Mengenal lingkungan, yaitu mengenal secara objektif lingkungan sosial dan lingkungan fisik serta menerimanya secara positif dan dinamis pula (Depdiknas, 2004).

Bruner dan Lewis (2006) menyatakan bahwa kesiapan psikologis menghadapi bencana dapat diberikan secara multilevel, pada tingkat sekolah dan tingkat kelas. Secara khusus, untuk layanan bimbingan pribadi dan sosial dengan tujuan meningkatkan kesiapan psikologis siswa, guru pembimbing lebih tepat memberikannya pada tingkat kelas, dengan bidang garapan melatihkan kemampuan untuk mandiri (termasuk menyelamatkan diri) dan kepedulian untuk membantu orang lain atau sesama. Dengan demikian, melalui bimbingan pribadi dan bimbingan sosial, guru pembimbing dapat meningkatkan kesiapsiagaan psikologis menghadapi bencana yang akan dapat mengurangi resiko terhadap akibat bencana alam (Watts, 2007).

Adapun yang dimaksud dengan kesiapan psikologis ialah kondisi psikis untuk mampu mengantisipasi dan mereaksi secara cepat dan tepat terhadap stimulus yang dihadapi, baik secara kognitif, afektif, maupun psikomotorik. Terkait dengan batasan ini, strategi bimbingan yang dapat diberikan siswa juga meliputi pengelolaan kognitif, pengelolaan afektif, serta pelatihan secara psikomotorik (Ayriza, 2007).

Pada strategi bimbingan untuk tujuan pengelolaan kognitif, siswa diajak untuk dapat memahami penyebab bencana, peluang bencana dan dampaknya, karakteristik bencana, sumber-sumber bahaya dari lingkungan, serta cara-cara mengukur tingkat bahaya di lingkungan. Pemahaman yang lebih baik tentang respon psikologis terhadap situasi peringatan adanya bencana alam, akan membantu orang merasa lebih percaya diri, lebih mampu mengendalikan, dan mempersiapkan lebih baik secara psikologis maupun mempersiapkan perencanaan-perencanaan darurat yang lebih efektif (Raser and Morrissey, 2009). Strategi bimbingan dalam bentuk pengelolaan afektif berisi berbagai aktivitas yang pada intinya bertujuan agar siswa dapat membangun sendiri kesiapan mental menghadapi bencana, mampu membangun kepercayaan diri dan semangat hidup menghadapi bencana, serta mampu mengelola tanggapan traumatis akibat bencana. Pada strategi bimbingan dalam bentuk pelatihan psikomotorik, layanan bimbingan yang diberikan guru BK berisi berbagai aktivitas yang pada intinya dapat menguasai berbagai prosedur dan keterampilan penyelamatan diri dalam menghadapi berbagai bencana alam.

Untuk dapat melaksanakan layanan bimbingan pribadi dan sosial yang baik, guru pembimbing hendaknya menguasai keterampilan-keterampilan berupa apersepsi, membuka, menyampaikan layanan, dan keragaman dalam menggunakan materi dan media, keterampilan dalam melakukan evaluasi, dan keterampilan membimbing simulasi (Joyce \& Weil, 1996).

Sehubungan dengan sasaran subjek yang akan ditangani berada pada fase 
remaja, maka perlu metode penanganan yang disesuaikan dengan karakteristik remaja, baik ditinjau dari karakteristik kognitif, sosial maupun emosionalnya (Ayriza, 2007). Ditinjau dari aspek kognitif, remaja memiliki karakteristik berpikir kritis (mampu introspeksi tentang dirinya, kejadian masa lampau secara tajam) (Partini, 2006), maka metode penangan yang efektif bagi remaja adalah pemberian masalah berupa kasus-kasus untuk dipecahkan. Ditinjau dari aspek emosinya, remaja memiliki karakteristik sangat labil, maka metode penanganan yang efektif adalah metode pengelolaan emosi dengan relaksasi dan katarsis (penyaluran emosi melalui melukis, menari, menyanyi, menulis surat atau puisi). Ditinjau dari karakteristik aspek sosialnya, remaja mempunyai kecenderungan lebih dekat dengan teman sebaya (Partini, 2006), metode penanganan yang paling efektif adalah mengaktifkan kerjasama dengan kelompok sebayanya, dan menghindari penggunaan metode yang bersifat "menggurui".

Dengan demikian, dapat disimpulkan bahwa strategi bimbingan pribadisosial untuk meningkatkan kesiapan psikologis siswa SMA dalam menghadapi bencana alam dapat diberikan dengan metode yang menyesuaikan karakteristik perkembangan remaja, serta meliputiwilayah perilaku kognitif, afektif dan psikomotorik. Adapun metode layanan yang dapat digunakan antara lain adalah sebagai berikut.

\section{Metode Problem Solving}

Problem solving padahakikatnya adalah upaya untuk menyelesaikan masalah dengan menggunakan metode-me- tode ilmiah atau berfikir secara sistematis, logis, teratur, dan teliti. Tujuannya untuk memperoleh kemampuan dan kecakapan kognitif dalam memecahkan masalah secara rasional, lugas, dan tuntas. Untuk itu, diperlukan kemampuan dan penguasaan konsep-konsep, prinsip-prinsip generalisasi serta insight (Muhibbinsyah, 1997). Problem solving dapat diberikan pada siswa secara individual maupun kelompok. Secara individual, aktivitas problem solving dapat dilakukan dengan cara guru menugaskan siswa untuk menyelesaikan masalah tentang bencana alam. Selanjutnya, siswa mempresentasikan pendapatnya di hadapan teman-temannya diikuti tanya jawab. Secara kelompok, aktivitas problem solving dapat dilakukan melalui diskusi kelompok. Selain dapat menjembatani karakteristik kognitif siswa SMA yang cenderung kritis, diskusi kelompok juga dapat mewadahi karakteristik sosial remaja yang berorientasi teman sebaya. Melalui aktivitas ini siswa bersama teman sebaya dibimbing untuk menemukan sendiri pemecahan suatu masalah terkait dengan bencana dan strategi penanganannya.

\section{Metode Katarsis}

Metode ini tergolong sebagai metode stormy method, yaitu metode untuk memulihkan keseimbangan mental melalui pemberian kesempatan kepada siswa untuk menyalurkan emosi-emosinya yang cenderung meledak-ledak, baik secara verbal maupun secara nonverbal. Beberapa aktivitas dengan metode katarsis ini dapat dilakukan melalui simulasi, yaitu dengan cara memperagakan beberapa aktivitas yang di- 
lakukan ketika bencana alam terjadi. Pada aktivitas ini siswa dapat mengekspresikan perasaannya tanpa takut, malu, atau ditolak lingkungannya.

\section{Metode Belajar melalui Modul}

Bimbingan melalui media modul merupakan salah satu teknik bimbingan pribadi sosial secara tidak langsung. Bimbingan ini menempatkan peran aktif siswa untuk mempelajari topik tertentu berkaitan dengan bencana alam dan strategi penanganannya tanpa guru terlibat aktif di dalamnya. Untuk melaksanakan kegiatan bimbingan ini, guru pembimbing dapat menyusun modul tentang strategi penanganan bencana dan penanganannya. Materi dapat diperoleh guru pembimbing dari berbagai sumber baik buku-buku referensi, artikel, internet, atau CD. Selanjutnya, materi yang ada diolah dan disusun berdasarkan aturan penulisan modul. Setelah modul tersusun, guru pembimbing dapat menugaskan pada siswa untuk membaca dan sekaligus mengukur kemampuan pemahaman siswa.

\section{Metode Peer Support}

Peer support merupakan salah satu aktivitas bimbingan untuk meningkatkan kesiapan psikologis menghadapi bencana alam dengan cara melibatkan siswa dalam membimbing teman sebayanya sendiri. Metode yang digunakan dapat berbentuk peer tutoring atau peer education, siswa yang sudah terseleksi dan terlatih diminta untuk menyampaikan materi tentang kesiapan psikologis menghadapi bencana pada teman sebayanya sendiri. Adapun fungsi peer educator atau peer tutor adalah se- bagai sahabat, fasilitator, dan pemimpin.

Berbekal pengalaman unik dan khas dari guru pembimbing, guruakan mampu memberikan bekal kesiapsiagaan psikologis menghadapi bencana kepada siswa. Hal ini merupakan satu wujud tantangan dari tugas yang senantiasa berkembang sesuai dengan konteks dan kebutuhan. Melalui strategi coping dan berbagai strategi yang lain guru akan mampu memberikan berbagai pengalaman dan contoh-contoh untuk mengembangkan keterampilan dan pengetahuan siswa menghadapi bencana alam (Chibbaro dan Jackson, 2006). Dampak lebih jauh seseorang akan lebih tenang sehingga dengan kesiapsiagaan psikologis tersebut akan mampu berfikir jernih untuk bisa membantu keluarga, dan orang lain untuk menyelamatkan diri.

Dari hasil penelitian, manfaat kesiapan psikologis yang diberikan dalam bimbingan terhadap situasi peringatan bencana alam telah mendapatkan dukungan empirik secara kuat (Morrissey \& Raser, 2003), serta menghasilkan literatur hasil penelitian yang luas dengan dasar bukti-bukti di bidang klinis dan kesehatan (Zeidner \& Endler, 1996).

Berdasar hasil penelitian tahun pertama yang telah mengembangkan dan memvalidasi modul bagi guru BK untuk memberikan layanan bimbingan pribadi dan sosial kepada siswa SMA dengan tujuan meningkatkan kesiapan psikologis dalam menghadapi bencana alam, penelitian pada tahun kedua ini didesain untuk sosialisasi modul layanan bimbingan kesiagaan bencana tersebut, sekaligus memberikan pelatihan 
penerapan modul. Oleh karena itu, penelitian ini bertujuan untuk mengetahui apakah ada peningkatan keterampilan guru dalam melaksanakan layanan bimbingan pribadidan sosial untuk meningkatkan kesiapan psikologis siswa dalam menghadapi bencana alam sebagai hasil dari pelatihan pengaplikasian modul.

Diharapkan penelitian ini mampu memberikan manfaat bagi guru-guru BKyang diberi pelatihan penerapan modul, agar mampu mengaplikasikannya dalam praktek layanan bimbingan pribadi-sosial sehingga kesiapan psikologis siswa dalam menghadapi bencana alam meningkatkan. Hipotesis yang diajukan dalam penelitian ini ialah: " ada perbedaan keterampilan guru dalam melaksanakan layanan bimbingan pribadi dan sosial untuk meningkatkan kesiapan psikologis siswa SMA dalam menghadapi bencana alam antara sebelum dan sesudah diberi pelatihan penerapan modul".

\section{METODE}

Pendekatan yang digunakan dalam penelitian ini adalah pendekatan Quasi Experiment dengan desain penelitian Pretest-Posttest, Non-Equivalent Control Group Design, yakni menggunakan pretest sebelum perlakuan diberikan. Pretest dalam penelitian ini juga digunakan untuk pengontrolan secara statistik serta dapat digunakan untuk melihat pengaruh perlakuan terhadap capaian skor (gain score). Desain tersebut digambarkan sebagai berikut.

$\begin{array}{lll}\begin{array}{l}\text { Intact Pretest } \\ \text { classes }\end{array} & \begin{array}{l}\text { Experimental } \\ \text { variable }\end{array} & \text { Posttest } \\ \text { Class } 1 \mathrm{O}_{1} & \text {--- } & \text { Approach } \\ & \left(\mathrm{X}_{1}\right) & \text {---- } \mathrm{O}_{2} \\ & & \end{array}$

(Sumber: Tim Puslitjaknov, Pusat Penelitian dan Inovasi Pendidikan, Balitbang Depdiknas, 2008)

Penelitian Quasi Eksperiment bertujuan untuk mengkaji kemungkinan hubungan sebab akibat dalam keadaan yang tidak memungkinkan ada kontrol/ kendali, tetapi dapat diperoleh informasi (Sukamto, 2008).

Variabel kerja penelitian yaitu keterampilan guru BK melaksanakan layanan bimbingan pribadi-sosial untuk meningkatkan kesiapan psikologis siswa SMA dalam menghadapi bencana alam. Keterampilan ini meliputi pemahaman secara kognitif tentang berbagai kebencanaan dan cara mengatasinya, kesiapan afektif untuk mengantisipasi berbagai keadaan sebelum, pada saat dan sesudah bencana alam, serta keterampilan melaksanakan layanan bimbingan pribadi-sosial.

Subjek penelitian adalah guru-guru BK SMA di DIY. Sampel penelitian pada penelitian ditetapkan 75 orang guru BK di DIY dengan menggunakan teknik quota area random sampling. Caranya yaitu tiap kabupaten atau kota diambil sampel sejumlah 15 orang guru masingmasing dari 15 sekolah, dan penentuan 15 sekolah dari tiap-tiap wilayah ini dilakukan secara random. Namun demikian, pada waktu pelatihan yang hadir hanya 29 orang guru karena adanya berbagai kegiatan ke-BK-an yang bersamaan.

Metode pengumpulan data yang digunakan baik adalah metode tes untuk mengungkap aspek kognitif, metode angket dengan bentuk skala untuk mengungkap data afektif dan metode observasi untuk mengungkap data psi- 
komotorik. Metode analisis data yang dugunakan adalah teknik deskriptif kuantitatif dan teknik statistik t-tes dengan program SPSS.

\section{HASIL DAN PEMBAHASAN}

Penelitian tahun kedua ini bertujuan untuk melatihkan penerapan modul bimbingan yang sudah dikembangkan pada tahun pertama kepada guru BK, agar guru terampil memberikan layanan bimbingan pribadi sosial kepada siswa SMA sehingga kesiapan psikologis siswa dalam menghadapi bencana alam meningkat.

Secara rinci kegiatan yang dilakukan adalah sebagai berikut.

\section{Proses Pelatihan}

Sosialisasi dan pelatihan diselenggarakan selama 2 hari, yaitu hari Sabtu dan Minggu tanggal 6 dan 7 Juni 2009 di ruang siđang I FIP UNY. Kegiatan ini meliputi hal-hal seperti berikut.

- Hari pertama berupa pembukaan dan kontrak belajar.

- Dilanjutkan dengan pretest, yang meliputi pretest tertulis (aspek kognitif dan afektif) serta pretest keterampilan memberikan layanan bimbingan pribadi dan sosial.

- Setelah kegiatan pretest, kegiatan dilanjutkan dengan materi kebencanaan yang disampaikan oleh pakar geografi. Isi materi secara umum berupa uraian tentang bencana gempa bumi, gunung meletus, angin puting beliung, sebab-sebab, karakteristik, dan strategi kesiapsiagaannya.

- Setelah materi kebencanaan, dilanjutkan dengan materi berupa strategi bimbingan untuk siaga bencana pada siswa SMA.

- Pelatihan dilanjutkan dengan materi tentang strategi layanan yang disesuaikan dengan karakteristik perkembangan remaja.

- Guru diberi tugas untuk menyusun materi layanan bimbingan pribadisosial dengan tujuan meningkatkan kesiapan psikologis siswa menghadapi bencana alam, serta melaksanakan layanan bimbingan di 3 sekolah, masing di Sleman, Bantul dan Kodya, dengan menggunakan metode bimbingan yang disesuaikan dengan karakteristik remaja.

\section{Tahap Evaluasi}

Setelah pelaksanaan pelatihan selesai, dilakukan evaluasi dengan memberikan post test pada guru untuk mengukur efektivitas pelatihan penerapan modul. Hasil post test meliputi aspek kognitif, afektif dan psikomotorik. Hasil perbandingan antara pre- dan post-test dapat dilihat pada bagian berikut ini.

\section{Penyajian Data Deskriptif}

Berdasar analisis data, diperoleh hasil perbandingan pre-test dan posttest pada aspek kognitif seperti berikut. 
Tabel 1. Hasil Pre Test dan Post Test untuk Aspek Kognitif Guru

\begin{tabular}{lccccc}
\hline \multirow{2}{*}{ Kategori } & Interval & \multicolumn{2}{c}{ Jumlah (orang) } & \multicolumn{2}{c}{ Persentase (\%) } \\
\cline { 3 - 6 } & & Pretest & Post test & Pretest & Post test \\
\hline Sangat tinggi & $23-30$ & 7 & 26 & 24,1 & 89,7 \\
Tinggi & $18-22$ & 18 & 3 & 62,1 & 10,3 \\
Sedang & $13-17$ & 4 & 0 & 13,8 & 0 \\
Rendah & $8-12$ & 0 & 0 & 0 & 0 \\
Sangat rendah & $0-7$ & 0 & 0 & 0 & 0 \\
& & 29 & 29 & 100 & 100 \\
\hline
\end{tabular}

Berdasarkan Tabel 1 di atas, dapat diketahui bahwa ada peningkatan proporsi subjek yang masuk dalam kategori sangat tinggi pemahamannya terhadap bencana. Hal ini terjadi karena ada peningkatan pemahaman terhadap bencana alam dari kelompok subjek yang sebelumnya dari kategori sedang dan tinggi berpindah ke kelompok kategori yang lebih tinggi sehingga apabila dicermati, kelompok kategori se- dang yang sebelumnya 4 orang $(13,8 \%)$ menjadi 0 orang $(0 \%)$, dan kelompok kategori tinggi yang sebelumnya 18 orang $(62,1 \%)$ menjadi 3 orang $(10,3 \%)$. Sementara kelompok kategori sangat tinggi yang sebelum pelatihan sebanyak 7 orang $(24,1 \%)$ meningkat menjadi 26 orang $(89,7 \%)$ setelah pelatihan.

Adapun hasil pretest dan post test untuk aspek afektif tampak dalam Tabel 2 seperti berikut.

Tabel 2. Kategorisasi Hasil Pre Test dan Post Test untuk Aspek Afektif Guru

\begin{tabular}{lccccc}
\hline \multirow{2}{*}{ Kategori } & Interval & \multicolumn{2}{c}{ Jumlah (orang) } & \multicolumn{2}{c}{ Persentase (\%) } \\
\cline { 3 - 6 } & & Pretest & Post test & Pretest & Post test \\
\hline Sangat tinggi & $66-80$ & 4 & 15 & 13,8 & 51,7 \\
Tinggi & $56-65$ & 18 & 12 & 62,1 & 41,4 \\
Sedang & $45-55$ & 7 & 2 & 24,1 & 6,9 \\
Rendah & $35-44$ & 0 & 0 & 0 & 0 \\
Sangat rendah & $20-34$ & 0 & 0 & 0 & 0 \\
& & 29 & 29 & 100 & 100 \\
\hline
\end{tabular}

Berdasarkan Tabel 2 di atas, dapat diketahui bahwa ada peningkatan proporsi subjek yang masuk dalam kategori sangat tinggi pada tingkat kesiapan afeksinya terhadap bencana. Hal ini terjadi karena ada peningkatan kesiapan afektif terhadap bencana alam dari kelompok subjek yang sebelumnya dari kategori sedang dan tinggi berpindah ke kelompok kategori yang lebih tinggi, sehingga apabila dicermati, kelompok kategori sedang yang sebelumnya 7 orang $(24,1 \%)$ menjadi 2 orang $(6,9 \%)$, dan kelompok kategori tinggi yang sebelumnya 18 orang $(62,1 \%)$ menjadi 12 orang $(41,4 \%)$. Sementara kelompok kategori sangat tinggi yang sebelum pelatihan sebanyak 4 orang $(13,8 \%)$ meningkat menjadi 15 orang $(51,7 \%)$ setelah pelatihan. 
Hasil pretest dan post test untuk aspek psikomotorik atau keterampilan tampak dalam Tabel 3. Berdasarkan tabel tersebut dapat diketahui bahwa terjadi peningkatan proporsi subjek yang termasuk dalam kategori tinggi dan sangat tinggi keterampilannya dalam melakukan bimbingan kesiapsiagaan psikologis terhadap siswa dalam menghadapi bencana. Sebelum pelatihan, kelompok subjek kategori tinggi hanya 1 orang $(3,4 \%)$ meningkat menjadi 7 orang $(24,1 \%)$, dan dari kelompok subjek kategori sangat tinggi, sebelum pelatihan tidak ada subjek yang mencapai kategori tersebut, akan tetapi setelah pelatihan meningkat secara drastis menjadi 15 orang $(51,7 \%)$.

Tabel 3. Hasil Pre Test dan Post Test untuk Aspek Psikomotorik/Keterampilan Guru

\begin{tabular}{|c|c|c|c|c|c|}
\hline \multirow[t]{2}{*}{ Kategori } & \multirow[t]{2}{*}{ Interval } & \multicolumn{2}{|c|}{ Jumlah (orang) } & \multicolumn{2}{|c|}{ Persentase $(\%)$} \\
\hline & & Pretest & Post test & Pretest & Post test \\
\hline Sangat tinggi & $24-31$ & 0 & 15 & 0 & 51,7 \\
\hline Tinggi & $19-23$ & 1 & 7 & 3,4 & 24,1 \\
\hline Sedang & $13-18$ & 7 & 6 & 24,1 & 20,7 \\
\hline Rendah & $8-12$ & 6 & 1 & 20,7 & 3,4 \\
\hline Sangat rendah & $0-7$ & 15 & 0 & 51,7 & 0 \\
\hline \multicolumn{2}{|c|}{ Jumlah } & 29 & 29 & 100 & 100 \\
\hline
\end{tabular}

Hal ini terjadi karena ada peningkatan keterampilan dari kelompok subjek yang sebelumnya pada kategori sangat rendah 15 orang $(51,7 \%)$ menjadi 0 orang $(0 \%)$, dari kelompok subjek kategori rendah yang sebelumnya 6 orang $(20,7 \%)$ menjadi 1 orang $(3,4 \%)$, dan dari kelompok subjek kategori sedang yang sebelumnya 7 orang $(24,1 \%)$ menjadi 6 orang $(20,7 \%)$, kelompok tersebut berpindah ke kelompok yang kategorinya lebih tinggi. Namun demikian, apabila dicermati, pada kelompok kategori sangat rendah dan rendah telah terjadi peningkatan yang cukup menyolok, sementara pada kelompok kategori sedang, hanya 1 orang $(3,4 \%)$ yang mengalami peningkatan keterampilannya ke kategori yang lebih tinggi. Hal ini bisa jadi disebabkan oleh kelompok subjek yang sudah memiliki keterampilan sedang atau cukup merasa kurang termo- tivasi untuk meningkatkan keterampilannya lagi ke kategori yang lebih tinggi.

\section{Hasil $t$-test}

\section{- Aspek kognitif}

Pengujian hasil pre-test dan post test pada aspek kognitif dengan menggunakan t-test dapat dilihat pada Tabel 4 . Berdasarkan Tabel 4, dapat diketahui bahwa ada perbedaan rata-rata antara pretest $(20,79)$ dengan post test $(27,62)$ pada keterampilan aspek kognitif. Perbedaan sebesar $-6,828(27,62-20,79)$ ini signifikan pada taraf signifikansi 0,05 dengan nilai $\mathrm{t}=-10,397$. Dengan demikian, dapat disimpulkan ada peningkatan yang signifikan mengenai kesiapan psikologis aspek kognitif dalam menghadapi bencana alam antara sebelum dan sesudah pelatihan. Hal ini berarti keterampilan guru dalam melaksanakan layanan bimbingan agar siswa me- 
mahami tentang seluk beluk bencana alam, termasuk penyebab bencana, potensi bencana dan dampaknya, karakterisitik bencana, sumber-sumber bahaya dari lingkungan, serta cara-cara meng- ukur tingkat bahaya di lingkungan mengalami peningkatan yang berarti dibandingkan keterampilan mereka sebelum diberi pelatihan.

Tabel 4. Hasil t-test dari Pre Test dan Post Test pada Aspek Kogitif Guru

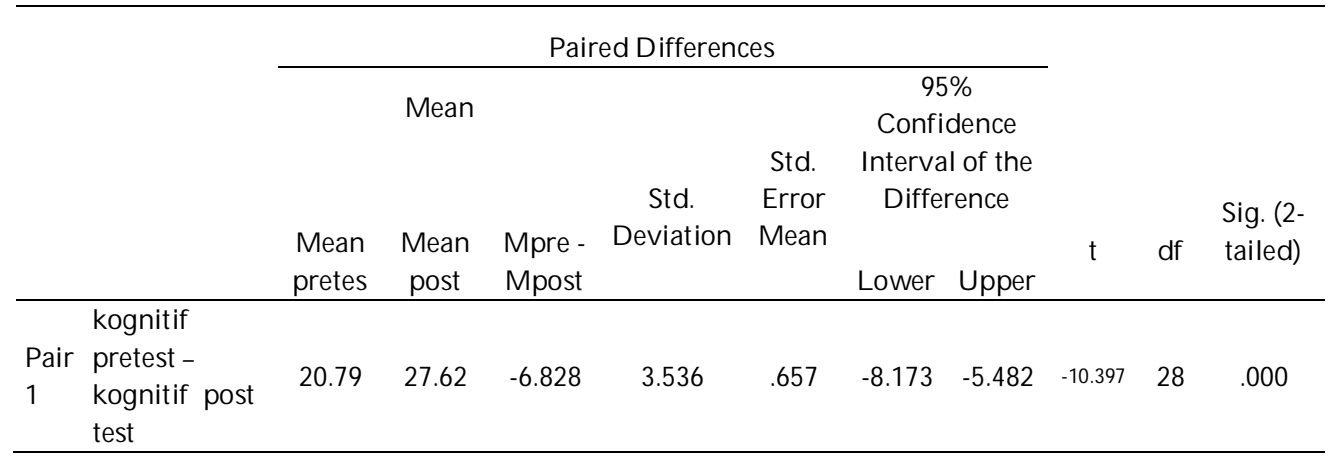

\section{- Aspek afektif}

Pengujian hasil pretest dan post test pada aspek afektif dengan mengguna- kan $t$-test menunjukkan hasil seperti pada Tabel 5 berikut.

Tabel 5. Hasil t-test dari Pre Test dan Post Test pada Aspek Afektif Guru

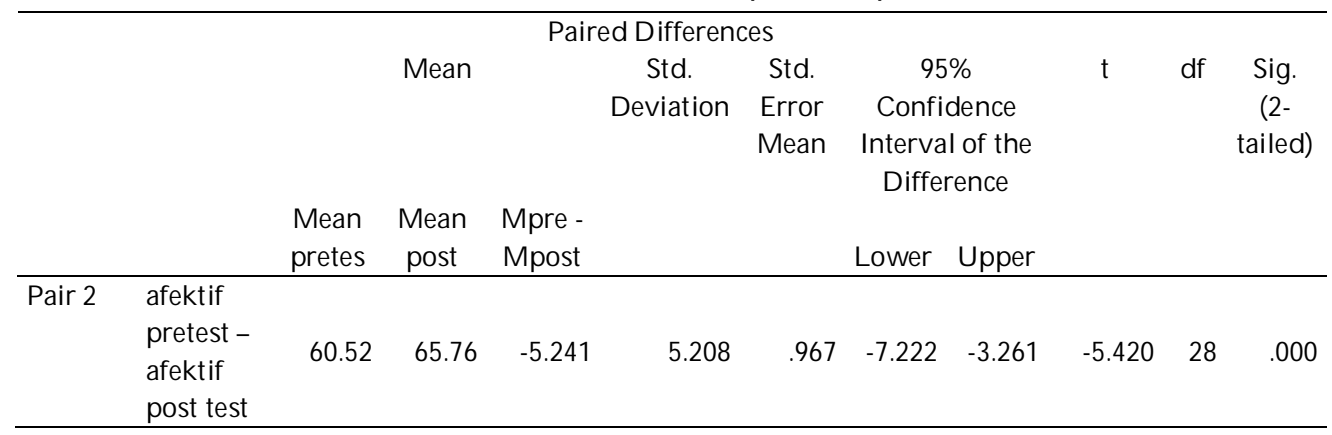

Tabel 5 di atas menunjukkan bahwa ada perbedaan rata-rata antara pretest $(60,52)$ dengan post test $(65,76)$ pada keterampilan aspek afektif. Perbedaan sebesar $-5,241(60,52-65,76)$ ini signifikan pada taraf signifikansi 0,05 dengan nilai $t=-5,420$. Dengan demikian, dapat disimpulkan ada peningkatan yang signifikan mengenai kesiapan psikologis as- pek afektif dalam menghadapi bencana alam antara sebelum dan sesudah pelatihan. Hal ini berarti keterampilan guru dalam melaksanakan layanan bimbingan untuk membantu siswa mengelola afeksinya terhadap bencana, meliputimembangun kesiapan mental menghadapi bencana, membangun kembali kepercayaan diri dan semangat hidup 
pasca bencana, serta mengelola tanggapan traumatis akibat bencana mengalami peningkatan yang berarti dibandingkan keterampilan mereka sebelum diberi pelatihan.

\section{- Aspek psikomotorik}

Pengujian hasil pretest dan post test pada aspek psikomotorik dengan menggunakan $t$-test menunjukkan hasil sebagai berikut.

Tabel 6. Hasil t-test dari Pre Test dan Post Test pada Aspek Psikomotorik/Keterampilan Guru

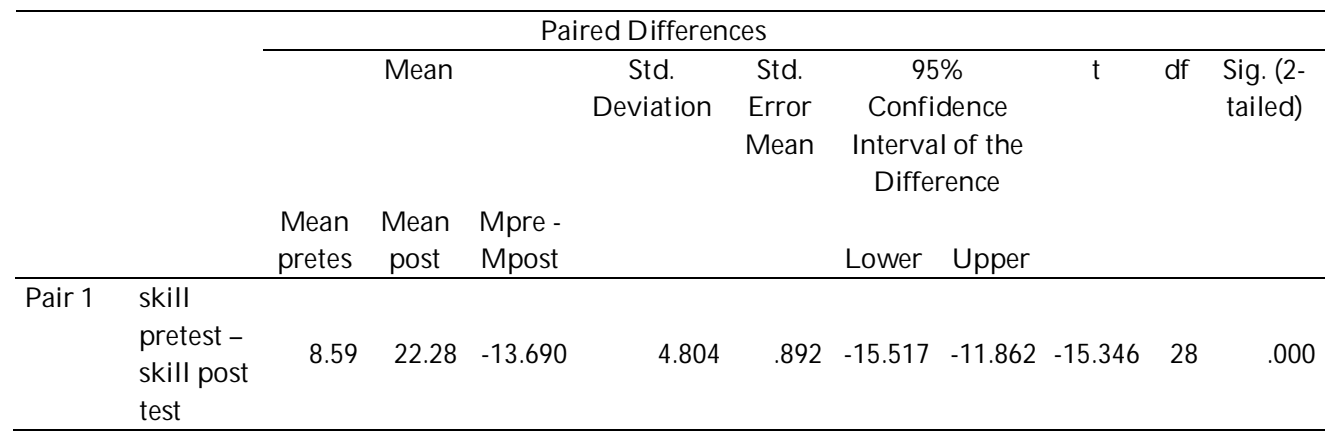

Tabel 6 di atas menunjukkan bahwa ada perbedaan rata-rata antara pretest $(8,59)$ dengan post test $(22,28)$ pada keterampilan aspek psikomotorik. Perbedaan sebesar -13,690 $(8,59-8,59)$ ini signifikan pada taraf signifikansi 0,05 dengan nilai $t=-15,346$. Dengan demikian, dapat disimpulkan ada peningkatan yang signifikan mengenai keterampilan guru dalam melaksanakan layanan bimbingan pada aspek psikomotorik antara sebelum dan sesudah pelatihan. Hal ini berarti bahwa keterampilan guru dalam melaksanakan layanan bimbingan untuk mengadakan berbagai aktivitas agar siswa dapat menguasai berbagai prosedur dan keterampilan penyelamatan diri dalam menghadapi bencana alam mengalami peningkatan yang berarti dibandingkan keterampilan mereka sebelum diberi pelatihan.

Tabel 7. Hasil t-test dari Pre Test dan Post Test pada Keterampilan Guru Melaksanakan Bimbingan

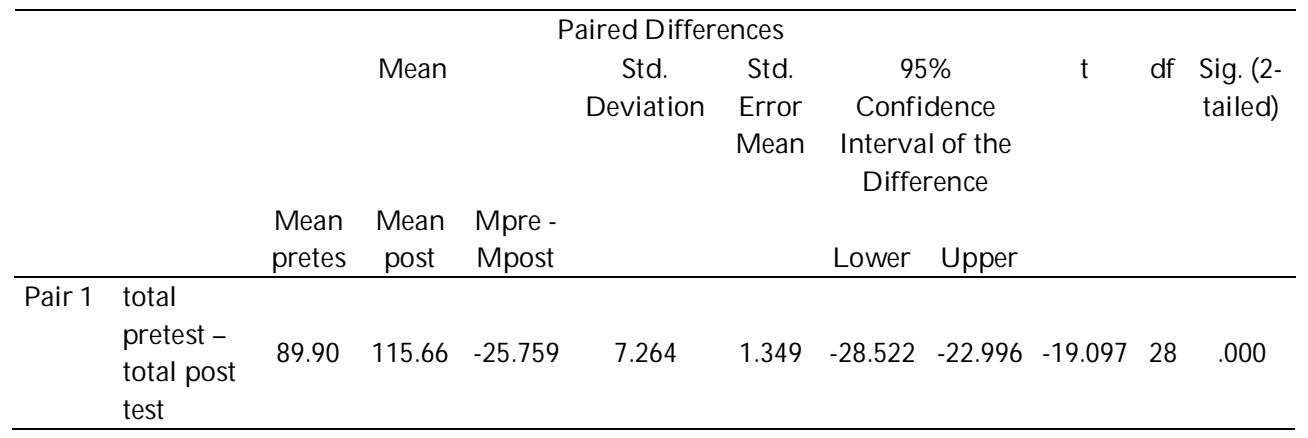


Berdasarkan hasil analisis secara keseluruhan yang tertuang dalam tabel 7 di atas, terlihat ada ada perbedaan rata-rata antara pretest $(89,90)$ dengan post test $(115,66)$ pada keterampilan membimbing secara keseluruhan. Perbedaan sebesar -25,759 $(89,90-115,66)$ ini signifikan pada taraf signifikansi 0,05 dengan nilai $\mathrm{t}=-19,097$, maka hipotesis kerja yang menyatakan "Ada perbedaan keterampilan guru dalam melaksanakan layanan bimbingan pribadi dan sosial untuk meningkatkan kesiapan psikologis siswa SMA dalam menghadapi bencana alam antara sebelum dan sesudah diberi pelatihan penerapan modul" dapat diterima. Artinya, keterampilan guru dalam melaksanakan layanan bimbingan pribadi dan social dengan tujuan meningkatkan kesiapan psikologis siswa dalam menghadapi bencana alam mengalami peningkatan signifikan antara sebelum dan sesudah pelatihan, baik dalam membantu siswa memahami seluk beluk tentang bencana alam, mengelola afeksi siswa pada saat sebelum dan pasca bencana, serta keterampilan membimbing siswa menguasai berbagai prosedur dan keterampilan penyelamatan diri dalam situasi bencana. Adapun yang dimaksud keterampilan membimbing secara spesifik meliputi keterampilan mengadakan apersepsi, keterampilan membuka, keterampilan menyampaikan layanan, keterampilan dan keragaman dalam menggunakan materi dan media, keterampilan dalam melakukan evaluasi, dan keterampilan membimbing simulasi.

Meningkatnya keterampilan guru dalam melaksanakan layanan bimbingan untuk meningkatkan kesiapan psiko- logis siswa dalam menghadapi bencana alam juga didukung dengan data tentang terjadinya peningkatan yang signifikan dalam kesiapan psikologis siswa dalam menghadapi bencana alam (hasil ini dipublikasikan pada proceeding diseminasi hasil-hasil penelitian tingkat nasional bidang pendidikan, olahraga, kajian wanita dan gender yang diselenggarakan oleh lemlit UNY pada tanggal 5 desember 2009).

\section{PENUTUP}

Berdasar hasil análisis data, dapat ditarik kesimpulan bahwa ada peningkatan yang signifikan pada keterampilan guru dalam melaksanakan layanan bimbingan pribadi-sosial dengan tujuan meningkatkan kesiapan psikologis siswa dalam menghadapi bencana alam antara sebelum dan sesudah pelatihan penerapan modul bimbingan, baik dalam membantu siswa memahami seluk beluk tentang bencana alam, mengelola afeksi siswa pada saat sebelum dan pasca bencana, serta keterampilan membimbing siswa menguasai berbagai prosedur dan keterampilan penyelamatan diri dalam situasi bencana. Adapun yang dimaksud keterampilan membimbing secara spesifik meliputi keterampilan mengadakan apersepsi, keterampilan membuka, keterampilan menyampaikan layanan, keterampilan dan keragaman dalam menggunakan materi dan media, keterampilan dalam melakukan evaluasi, dan keterampilan membimbing simulasi. 


\section{SARAN}

Dengan berdasar hasil penelitian yang menunjukkan efektivitas penerapan modul bimbingan untuk meningkatan kesiapan psikologis siswa dalam menghadapi bencana alam, serta frekuensi terjadinya bencana alam yang cukup tinggi di berbagai wilayah Indonesia secara silih berganti, maka diajukan beberapa saran seperti berikut.

- Modul bimbingan yang sudah dikembangkan dengan tujuan meningkatkan kesiapan psikologis siswa dalam menghadapi bencana alam dapat disosialisasikan oleh pemegang kebijakan kepada para guru pembimbing, agar dalam layanan bimbingan pribadi dapat mengintegrasikan materi siaga bencana ke dalam kurikulum dengan berpanduan pada modul tersebut.

- Pengembangan modul dapat diperluas dengan jenis-jenis bencana yang lain dan wilayah penelitian yang lebih luas sebagai salah satu usaha mitigasi dan membangun ketahanan bangsa melalui ketahan sekolah.

\section{UCAPAN TERIMA KASIH}

Pada kesempatan ini, kami mengucapakan terima kasih kepada Dirjen Dikti yang telah memberikan dana untuk penelitian ini, kepada tim peneliti: Dr. Muh. Nurwangit, Siti Rochmah Nurhayati, MSi, dan Kartika Nur Fathiyah, MSi, dan kepada tim Redaktur dan staf Jurnal Cakarawala Pendidikan Universitas Negeri Yogyakarta yang telah memberi kesempatan untuk publikasi artikel ini.

\section{DAFTAR PUSTAKA}

Ayriza. 2007. "Kecemasan dan Trauma Menghadapi Bencana, serta Strategi Penanganannya dalam Rangka Membentuk Kesiapan Psikologis terhadap Potensi Bencana bagi Remaja Korban." Makalah. Disajikan pada Seminar Nasional mengenai Pemulihan Trauma Pasca Gempa Bumi 27 Mei 2006 di HotelMatahari, Diselenggarakan Pusat Studi Wanita UNY Bekerjasama dengan UNESCO PARIS Komisi Nasional Indonesia untuk UNESCO Depeartemen Pendidikan Nasional RI.

Brunner, J. dan Lewis, D. 2006. Planning for Emergencies. Principal Leadership. April 2006. 6; 8: p. 65-66.

Chibbaro, J. S. dan Jackson, C.M. 2006. Helping Students Cope in an Age of Terrorism: Strategies for School Counselor. Professional School Counseling. April 2006. 9: 4; p. 314-321.

Departemen Pendidikan Nasional. 2004. "Petunjuk Pelaksanaan BK Kurikulum SMU". Kurikulum SMU. Jakarta: Diknas.

Fathiyah K. N. 2007. Pengembangan Bahan Ajar mengenai Penyiapan Diri terhadap Bencana secara Psikologis (Psychological Disaster Preparedness) bagi Guru BK di SMA". Makalah. Disampaikan dalam Pelatihan Menyikapi Bencana untuk Guru ASPnet Bantul. Yogyakarta 27 Februari-1 Maret 2007. 
Joyce, B., \& Weil, M. 1996. Models of Teaching. Needam Heights, USA: Allyn \& Bacon.

Morrissey, S. A., \& Raser, J. P. 2003. "Evaluating the Effectiveness of Psychological Preparedness Advice in Community Cyclone Preparedness Materials". Australian Journal of Emergency Management, 18, 44-59.

Muhibbinsyah. 1997. Psikologi Pendidikan. Bandung: Remaja dan Rosda Karya.

Partini, S. dkk. 2007. Perkembangan Peserta Didik. Diktat Kuliah. Yogyakarta: FIP Universitas Negeri Yogyakarta.

Raser, J.P., \& Morrissey, S.A. 2009. “The Crucial Role of Psychological Preparedness for Disaster". Australian Psychological Society. Retrieved on August 19, 2009, from: http:// www.psychology.org.au/inpsych /psychological_preparedness/.
Sugihartono. 1989. Pokok-pokok Bimbingan dan Konseling di Sekolah. Yogyakarta: FIP IKIP Yogyakarta.

Sukamto. 1995. Seri Metodologi Penelitian: Panduan Penelitian Eksperimen. Yogyakarta: Lembaga Penelitian IKIP Yogyakarta.

Tim Puslitjaknov Balitbang Depdiknas. 2008. Metode Penelitian Pengembangan. Jakarta: Pusat Penelitian Kebijakan dan Inovasi Pendidikan Badan Penelitian dan Pengembangan Departemen Pendidikan Nasional.

UNDP. 2006. Kerangka Acuan Pelaksanaan Pelatihan Orientasi Pengurangan dan Manajemen Resiko Bencana. Makalah.

Watts, M.2007. Be Prepared: School Planning \& Management. Februari 2007. 46; 2: 20-25.

Zeidner, M., \& Endler, N. S. 1996. Handbook of Coping: Theory, Research, Application. New York: Willey \& Sons, Inc. 